\title{
Determinants of Micro-, Small- and Medium-Sized Enterprise Loans by Commercial Banks in Indonesia
}

\author{
Rizky YUDARUDDIN ${ }^{1}$
}

Received: July 03, 2020 Revised: July 25, 2020 Accepted: August 10, 2020

\begin{abstract}
This paper investigates, in a single equation framework, the effect of bank-specific and macroeconomic determinants on micro-, smalland medium-sized loans by commercial banks in Indonesia. This study uses a sample of 790 observations from 79 commercial banks in Indonesia over the years 2006-2015. This study uses two estimation methods for our panel regressions: static and dynamic generalized method of moments (GMM) panel estimator. In static relationships, the literature usually uses the least square methods on fixed effects (FE) or random effects (RE). I found evidence that all banks, bank profitability and size are positively and significantly related to micro-, smalland medium-sized loans, while the coefficients of liquidity are significantly positive in all specifications, except government banks which is significantly negative. The relationship between risk and credit growth is negative for non-government banks. All estimated equations show that the effect of the capital variable on lending banks to MSMEs is not important in government banks and non-government banks. Finally, macroeconomic variables, such as inflation and gross domestic product, clearly affect the lending of the banking sector particularly non-state banks. The findings have several policy implications to Indonesia government, regulatory authority and bank managers in order to improve bank profitability through bank lending.
\end{abstract}

Keywords: Micro Small and Medium Enterprise, Loans, Bank, Indonesia

JEL Classification Code: G20, G21

\section{Introduction}

The loan financing for Micro-, Small- and Mediumsized Enterprises (MSMEs) is one of the important issues for government in monetary policy and financial development. One of the interesting facts of MSMEs is that they account for a significant share of economic growth and employment. Using a sample of 45 countries, Beck et al. (2005) found a strong, positive association between the importance of SMEs and GDP per capita growth. Haltiwanger et al. (2013) has indeed confirmed a general tendency linking small- and

${ }^{1}$ First Author and Corresponding Author. Lecturer, Faculty of Economics and Business, Mulawarman University, Indonesia [Postal Address: Jl. Tanah Grogot No. 1, Samarinda Ulu, Gunung Kelua, Gn. Kelua, Kec. Samarinda Ulu, Kota Samarinda, Kalimantan Timur, 75117, Indonesia] Email: rizky.yudaruddin@feb.unmul.ac.id

(c) Copyright: The Author(s)

This is an Open Access article distributed under the terms of the Creative Commons Attribution Non-Commercial License (https://creativecommons.org/licenses/by-nc/4.0/) which permits unrestricted non-commercial use, distribution, and reproduction in any medium, provided the original work is properly cited. medium-sized enterprises to a dynamic of greater job creation in terms of numbers. Díaz-Chao et al. (2016) found that during the early years of the recessions, small- and mediumsized enterprises were able to do the greatest improvements to job quality. Xuan (2020) found that business lines, import and export business, type of business registration, business location, operating time, and the percentage of the organization's capital contribution are factoring that impact on the size of the investment capital of MSMEs. Therefore, bank lending plays an important role in explaining the effects of policy on the economy and the linkage between stability and regulatory policy (Kishan \& Opiela, 2000).

The development of MSME cannot be separated from to support of bank lending to MSME. The bank lending behavior support will assist MSME in running its business. Abe et al. (2015) found that the constraints facing MSMEs are financing. MSME owners do not effectively manage working capital and the asymmetric information between banks and MSME. Ramcharran (2017) found that bank loans are the main source of financing so that capital allocation and risk management policies are of primary concern. In addition, 
Beck et al. (2008) suggest that firm size has an important role in understanding financing patterns. Small companies use fewer external funds, especially bank finances.

The focus of Indonesian banking to MSMEs is very low. In the last five years, the growth of bank credit to MSMEs decreased. Based on the report of Bank Indonesia in 2016, it was noted that credit growth of $15.08 \%$ in 2013 decreased to $8.39 \%$ in 2016. Empirical studies of MSMEs in Indonesia found that MSME access to financing sources of banking needs to be improved (Susilo, 2007). Azis and Rusland (2009) disclose regulatory changes on Indonesian banks making the role of the Indonesian bank as a monetary policymaker to be limited. Target MSME as a separate and strategic customer group because of the difference in segments between MSMEs and corporations in their financial and operational needs (International Financial Corporation, 2016).

This paper investigates, in a single equation framework, the effect of bank-specific and macroeconomic determinants on bank lending behavior. The group of the bank-specific determinants of lending involves liquidity, capital, profitability, financial risk, and size of the bank. The second group of determinants relates bank lending to the macroeconomics within which the banking system operates. In this context, we include economic growth and inflation among the explanatory variables. This paper also provides further insight into the bank lending behavior by commercial banks in Indonesia. Toward this end, we employ a panel data set of commercial banks in Indonesia covering the period from 2006 to 2015. In specifying the model, we account for loan persistence using static and dynamic panel data estimation procedure. We focus on private firms, particularly MSMEs, due to financial constraints and asymmetric information constraints compared to other public firms (Beck et al., 2005).

The contributions of this study are as follows: first, this study compares bank lending behavior of state-owned and non-state-owned banks in order to give policy implications to government, bank managers, and the regulatory authority. The differentiation of bank lending behavior by ownership is interesting because private banks typically follow a business model that aims to maximize profits, while state-owned banks tend to follow social welfare-oriented goals rather than for-profit maximization (La Porta et al., 2002). The type of the lender is important for the extent of financial constraints faced by private firms and financial constraints of SMEs decrease if they increase their borrowings from state-owned banks relative to total bank borrowings (Behr et al., 2013). Government-owned banks are more responsive to economic shocks and are able to provide stabilization credit (Micco \& Panizza, 2006).

Second, only a few papers specifically investigated the determinants of lending behavior using MSME data. Berger et al. (2001) used data source for small businesses from The National Survey of Small Business Finance (NSSBF) in 1993 to examine the small business lending market, particularly the aspect of competition and size structure of a banking market. Berger et al. (2017) are also using data set containing information about small- and medium-sized enterprises in Italy, Germany, and the UK to investigate the correlation between small- and medium-sized enterprises' use of venture capital and bank financing. Goldberg et al. (2002) investigate banks' lending practices and procedures of small- and medium-sized enterprises in the U.S. as of year-end 1992, particularly analyzing the micro-level differences in the loan-approval processes of large and small banks. Behr et al. (2017) use panel data from around 800 German banks spanning the period from 1987 to 2007. They investigate whether the cyclicality of lending depends on government involvement in German banks

Finally, this paper also contributes to the existing literature on the determinants of bank lending behavior (e.g., Panagopoulos \& Spiliotis, 1998; Micco \& Panizza, 2006; Pham, 2013; Vo, 2018). Previous papers show that the bank lending behavior depends on both exogenous factors, such as gross domestic product and inflation (Molyneux et al., 1998; Dinc, 2005; Joen et al., 2006; Micco \& Panizza, 2006; Guo \& Stepanyan, 2011; Allen et al., 2013; Chen \& Wu, 2014; Yudaruddin, 2017) and bank-specific (Gambacorta \& Marques-Ibanez, 2003; Guo \& Stepanyan, 2011; Pontines \& Siregar, 2014; Choi, et al., 2013; Fungáčováa et al., 2013; Chen $\& \mathrm{Wu}, 2014)$. We extend this literature by documenting an effective way that provides banks in Indonesia with a simple method in understanding and evaluating bank lending behavior, as well as enhancing stabilization credit to MSMEs.

The paper is organized in the following manner. Section 2 discusses the existing literature on bank lending behavior. Section 3 presents variable selection as well as the empirical model. Section 4 presents the estimation method and the empirical results. Section 5 concludes the paper.

\section{Literature Review}

\subsection{Bank Specific Determinants}

In the literature, bank lending behavior is usually expressed as a function of internal and external determinants. The internal determinants could be termed micro or bank-specific determinants of lending such as liquidity, profitability, financial risk and size of the bank. The external determinants are variables that are not related to bank management but reflect the economic conditions that affects the operation and lending such as gross domestic product and inflation. 
Bank size is measured using total assets. The larger the bank, the greater the total assets it holds, which means the bank has a large fund as well. So, in probability, loan lending is also getting bigger. small- and medium-sized banks have a comparative advantage in lending to SMEs as they tend to interact more privately with their borrowers. smaller banks are better able to collect and act on soft information than large banks because large banks lend at greater distances, do not reduce credit constraints because impersonally with their borrowers, have shorter and less exclusive relationships, and not easing credit constraints as effectively (Berger et al., 2005). Size of the bank in which previous studies had found their bank size has a positive impact significantly (Gambacorta \& Marques-Ibanez, 2003; Joen et al., 2006) and a significant negative (Chen \& Wu, 2014; Pontines \& Siregar, 2014).

Profitability of banks is proxied by using return-onasset ratio. The higher the profitability, the better and more efficient the banking, because to obtain a large profitability required the existence of productive assets of quality and solid management. De Haas and Lelyveld (2006), Allen et al. (2013), and Mollyneux et al. (1998) found profitability to show a positive and significant sign. These conditions indicate that with high profitability, banks are more likely to increase the distribution of credit, thereby affecting the increased percentage of returns that will be received by banks. Conclusion from that research is that profitability becomes one indicator to measure credit growth rate. However, some studies such as De Haas and Lelyveld (2010) and Pontines and Siregar (2014) suggest profitability shows positive and insignificant signs. These conditions indicate that high profitability does not affect credit growth, but banks continue to increase lending bank.

Liquidity is one of the complex issues in bank operations. It is because the funds managed by the bank mostly are funds from the public that are short-term and can be withdrawn at any time. De Haas and Lelyveld (2006), Pontines and Siregar (2014), and Nguyen and Nguyen (2020) explained that liquidity shows a positive and significant sign. The condition indicates that with high liquidity, the bank is more likely to increase the distribution of credit, thereby affecting the increasing percentage of credit growth in line with the increase in the ability of banks to pay off their obligations that have matured. It can be concluded, based on the research, that liquidity becomes one factor in measuring credit growth rate. However, De Haas and Lelyveld (2014), Allen et al. (2013), De Haas and Lelyveld (2010), and Ferri et al. (2014) suggest liquidity to show a negative and significant sign. These conditions indicate that high liquidity affects the behavior of banks, which actually reduce their lending.

Solvency measured from the ratio of capital to total assets is expected to have a positive effect. The higher value of this ratio means that banks have sufficient capital to account for the risks. This means that if at any time the bank suffered losses due to operational activities such as bad debts, then the bank still has sufficient capital to deal with such losses, so the parties who keep the funds in the bank still feel safe. The higher the value of capital-to-total assets, then the possibility of credit offer that can be done by banks is also getting bigger. Chu et al. (2007) provide evidence that the information content is lowered only when lines of credit are issued by banks with lower level of capitalization. Allen et al. (2013), Chen and Wu (2014), Choi et al. (2013), Fungáčováa et al. (2013), Ferri et al. (2014) and Gambacorta and Marques-Ibanez (2003) found a significant positive sign between capital and loans

Measuring the risk of using Loan Loss Provision. Loan loss provisions can be an important prudential instrument for emerging countries because they play a role in the banking system, especially financial intermediation (Saurina, 2009; Bouvatier \& Lepetit, 2012; Takasu \& Nakano, 2019). Jiménez and Saurina (2006) show that there is a direct relationship between credit growth and credit risk, so that the rapid increase in loan portfolio is positively associated with an increase in the ratio of non-performing loans in the future. The relationship between risk and lending is negative. This means that increased risk will reduce credit growth. Cucinelli (2015), Pontines and Siregar (2014), and Guo and Stepanyan (2011) found a negative relationship between risk and credit growth of banks.

\subsection{Macroeconomic Determinants}

The relationship between economic conditions and existing bank lending behavior is based on ModiglianiMiller Theorem (1958), which states that the market value of a company is correctly calculated as the present value of its future earnings and its underlying assets, and is independent of its capital structure. Micco and Panizza (2006) examine the economic conditions where bank ownership interacts with the behavior of bank credit. The study found that GDP growth positively and significantly increases bank lending. In addition, the bank also discovered that the government was not more responsive to shocks than macroeconomic foreign and domestic banks. GDP is expected to have positive results against lending. This indicates increasing economic growth in the loan will be increased as well. Dinc (2005), Chen and Wu (2014), Guo and Stepanyan (2011), Joen et al. (2006), and Allen et al. (2013) showed similar results on real GDP growth of the loan portfolio. On Molyneux et al. (1998), Log GDP was also negative, but not significant effect on lending.

Variable inflation also has an impact on lending. A relation with the behavior of credit inflation is negative, which means the increase in inflation will reduce bank lending. Boyd and Champ (2006) find that countries with 
higher inflation normally have small banking and equity market, banks generally reduce credit especially the private sector. Allen et al. (2013) found a significant negative sign between inflation and credit growth.

\section{Research Methods}

This section identifies the sources of our data, presents the data, and describes the regression model that I used to investigate the effects of bank-specific and macroeconomic determinants on bank lending behavior.

Our main data source for the bank-specific such as liquidity, profitability, financial risk and size of the bank is Indonesia Banking Directory, which provides annual financial information for banks in Indonesia, while the macroeconomic data used in this study is the annual report data released by Indonesia's Central Statistics Agency (BPS). Our sample is a balanced panel dataset of 79 commercial banks in Indonesia, consisting of 790 observations over the years from 2006 to 2015. I divide the observations into two categories: observations on state-owned and non-government banks. The number of government-owned bank observations is 310 observations, while the non-government-owned bank is 480 observations. The general model is estimated in the following linear form:

$$
\begin{aligned}
\operatorname{LOAN}_{, i, t}= & \alpha_{i, t}+\beta_{1} \operatorname{LOAN}_{i, t-1}+\beta_{2} \operatorname{SIZE}_{i, t} \\
& +\beta_{3} \operatorname{PROF}_{i, t}+\beta_{4} L I Q_{i, t}+\beta_{5} S_{i, t} \\
& +\beta_{6} \operatorname{RISK}_{i, t}+\beta_{7} G D P_{, t}+\beta_{8} I N F_{t}+\varepsilon_{i, t}
\end{aligned}
$$

where independent variables used in this study are Lending Behavior, which is proxied with log natural bank credit (LOAN) including lagged micro-, small- and medium-sized enterprises loan $\left(\mathrm{LOAN}_{\mathrm{it}-1}\right)$ bank $\mathrm{i}$ at time t. Profitability is proxied with Return on Assets (PROF). Variable profitability is expected to show a positive effect. Solvency (SOL) measured from the ratio of capital-to-total assets profitability is expected a positive effect. Firm size (SIZE) as measured by log natural total assets. Liquidity (LIQ) is expected to be positive. Liquidity is measured by credit to third-party fund of banks the year t. So, the increase in the four variables (Profitability, Liquidity, Solvency and Size) encourages banks to provide more credit. Risk is proxied ratio Loan Loss Provision to Loan (RISK) is expected to be negative. In addition, other macroeconomic variables are also involved, namely, Gross Domestic Product (GDP) and inflation (INF). Growth Gross Domestic Product at Current Market Prices (billion rupiahs) and Inflation is measured by the consumer price index.

This study uses two estimation methods for our panel regressions: static and dynamic generalized method of moments (GMM) panel estimator. In static relationships, the literature usually uses the least square methods on fixed effects (FE) or random effects (RE) models though will cause bias due to diminishing time dimensions and inconsistent estimates (Baltagi, 2001). Therefore, I also use techniques for dynamic panel estimation that are able to deal with these inconsistencies of our estimates. This model uses the system GMM estimator to control for possible simultaneity and endogeneity problems in our model (Arellano \& Bond, 1991).

\section{Results and Discussion}

Table 1 provides the descriptive statistics for the variables used in the study. The average micro-, small- and mediumsized enterprises loan for all banks is 13.237 (standard deviation $=2.279$ ), whereas in state-owned banks and nonstate-owned banks are 13.921 and 12.794, respectively, with standard deviations of 2.084 and 2.293, respectively. Bank-specific and macroeconomic determinants such as liquidity, profitability, financial risk, size of the bank, GDP and inflation have an average value greater than the standard deviation. That means the value of each variable still represents each variable analyzed. Finally, the relevant specification tests for each estimated equation are presented.

Table 2 provides information on the degree of correlation between the explanatory variables used in the panel regression analysis. State-owned banks and non-state-owned banks have each a correlation are under 0.80 . It is the same for all banks that have the correlation are under 0.80 . Correlation matrix for the explanatory variables shows that, in general, the correlation between the explanatory variables is not strong, suggesting that multicollinearity problem is not severe.

The regression results focusing on the relationship between micro-, small- and medium-sized enterprises loan banks and the explanatory variables are presented in Table 3, 4 and 5. I use two estimation methods for our panel regressions: static and dynamic Generalized method of moments (GMM) panel estimator. The explanatory power of the estimation methods using fixed effects and random effects for all categories is reasonably high, while the F-statistic for all models is significant at the $1 \%$ level. The $\mathrm{R}$ square for all models is also considerably higher than 0,50. In addition to GMM panel estimator, the model seems to fit the panel data reasonably well, having fairly stable coefficients, while the Wald-test indicates fine goodness of fit and the Sargan-test shows no evidence of overidentifying restrictions for all models. The value test for the second-order autocorrelation (AR 2 errors), however, implies that the moment conditions of the model are valid for all category. The significant coefficients of the lagged dependent variables (micro, small and medium enterprises loan by ownership category) confirm the dynamic character of model specification. 
Table 1: Descriptive Statistics

\begin{tabular}{|c|c|c|c|c|c|}
\hline Variables & Mean & Std. Dev & Min. & Max. & Obs. \\
\hline \multicolumn{6}{|c|}{ Part A: All Banks } \\
\hline LOAN & 13.237 & 2.279 & 2.708 & 20.044 & 790 \\
\hline SIZE & 15.616 & 1.835 & 11.215 & 56.05 & 790 \\
\hline PROF & 15.237 & 12.508 & -73.62 & 25.255 & 790 \\
\hline LIQ & 0.321 & 0.149 & 0.0003 & 1.704 & 790 \\
\hline SOL & 0.147 & 0.135 & 0.014 & 2.999 & 790 \\
\hline RISK & 0.020 & 0.019 & $3.84 \mathrm{e}-06$ & 0.237 & 790 \\
\hline GDP & 8.817 & 0.400 & 8.113 & 9.353 & 790 \\
\hline INF & 6.219 & 2.516 & 2.78 & 11.06 & 790 \\
\hline \multicolumn{6}{|c|}{ Part B: State-owned banks } \\
\hline LOAN & 13.921 & 2.084 & 8.706 & 20.0440 & 310 \\
\hline SIZE & 16.213 & 1.535 & 13.567 & 20.556 & 310 \\
\hline PROF & 25.371 & 8.908 & -5.62 & 56.05 & 310 \\
\hline LIQ & 0.348 & 0.155 & 0.0003 & 0.951 & 310 \\
\hline SOL & 0.112 & 0.033 & 0.0145 & 0.214 & 310 \\
\hline RISK & 0.026 & 0.019 & 0.002 & 0.131 & 310 \\
\hline GDP & 8.817 & 0.400 & 8.113 & 9.353 & 310 \\
\hline INF & 6.219 & 2.516 & 2.78 & 11.06 & 310 \\
\hline \multicolumn{6}{|c|}{ Part C: Non-state-owned banks } \\
\hline LOAN & 12.794 & 2.293 & 2.708 & 18.330 & 480 \\
\hline SIZE & 15.230 & 1.910 & 11.215 & 20.182 & 480 \\
\hline PROF & 20.182 & 9.854 & -73.62 & 36.37 & 480 \\
\hline LIQ & 0.302 & 0.142 & 0.090 & 1.704 & 480 \\
\hline SOL & 0.169 & 0.168 & 0.049 & 2.999 & 480 \\
\hline RISK & 0.017 & 0.018 & $3.84 \mathrm{e}-06$ & 0.237 & 480 \\
\hline GDP & 8.817 & 0.400 & 8.113 & 9.353 & 480 \\
\hline INF & 6.219 & 2.516 & 2.78 & 11.06 & 480 \\
\hline
\end{tabular}

Turning to the other explanatory variables, the coefficient of size of the bank is positive and highly significant. Increased bank size will increase bank lending especially in non-government banks. However, this study found that, in government-owned banks using the GMM model, the size of the bank does not affect the lending bank because the state-owned banks have an obligation to support MSMEs even though the size of the bank is large or small. Over all, this result suggests that the size of the bank positively influences bank lending to MSMEs. This is consistent with the findings of previous studies by Berger et al. (2005), Gambacorta and Marques-Ibanez (2003), and Joen et al. (2006) who document that the size of the bank positively influences bank lending to MSMEs.

Using the GMM model, the empirical results show that profitability affects bank lending to MSMEs positively and significant. This result is in accordance with the expectation, which shows the increasing profitability leads to more lending banks to MSMEs. Therefore, the result is also 
Table 2: Correlation Matrix for the Explanatory Variables

\begin{tabular}{|c|c|c|c|c|c|c|c|}
\hline \multicolumn{8}{|c|}{ Part A: All Banks } \\
\hline & SIZE & PROF & SOL & LIQ & RISK & GDP & INF \\
\hline SIZE & 1.0000 & & & & & & \\
\hline PROF & 0.4075 & 1.0000 & & & & & \\
\hline LIQ & -0.3704 & -0.2463 & 1.0000 & & & & \\
\hline SOL & -0.2104 & 0.1686 & 0.3015 & 1.0000 & & & \\
\hline RISK & 0.1875 & 0.0386 & 0.0716 & 0.1685 & 1.0000 & & \\
\hline GDP & 0.2447 & -0.0767 & 0.0432 & -0.3802 & -0.2387 & 1.0000 & \\
\hline INF & -0.0513 & 0.0108 & 0.0434 & -0.0172 & 0.0012 & -0.1956 & 1.0000 \\
\hline \multicolumn{8}{|c|}{ Part B: State-owned banks } \\
\hline & SIZE & PROF & SOL & LIQ & RISK & GDP & INF \\
\hline SIZE & 1.0000 & & & & & & \\
\hline PROF & -0.0560 & 1.0000 & & & & & \\
\hline LIQ & -0.1932 & -0.0392 & 1.0000 & & & & \\
\hline SOL & -0.2648 & 0.2512 & -0.2986 & 1.0000 & & & \\
\hline RISK & 0.2059 & -0.2937 & 0.0322 & 0.1058 & 1.0000 & & \\
\hline GDP & 0.2613 & -0.1457 & 0.3549 & -0.5867 & -0.2104 & 1.0000 & \\
\hline INF & -0.0524 & 0.0431 & 0.0128 & 0.0565 & 0.0346 & -0.1956 & 1.0000 \\
\hline \multicolumn{8}{|c|}{ Part C: Non-state-owned banks } \\
\hline & SIZE & PROF & SOL & LIQ & RISK & GDP & INF \\
\hline SIZE & 1.0000 & & & & & & \\
\hline PROF & 0.5025 & 1.0000 & & & & & \\
\hline LIQ & -0.3845 & -0.1874 & 1.0000 & & & & \\
\hline SOL & -0.2643 & -0.0047 & 0.5038 & 1.0000 & & & \\
\hline RISK & 0.0995 & -0.0571 & 0.1613 & 0.1652 & 1.0000 & & \\
\hline GDP & 0.2516 & -0.0752 & 0.0112 & -0.2429 & -0.2697 & 1.0000 & \\
\hline INF & -0.0540 & -0.0027 & 0.0559 & -0.0694 & -0.0221 & -0.1956 & 1.0000 \\
\hline
\end{tabular}

consistent with De Haas and Lelyveld (2006), Allen et al. (2013), and Mollyneux et al. (1998). This result indicates that the profit achieved by banks will be the consideration of banks in lending banks to MSMEs.

The coefficients of liquidity measure, credit to third-party fund of banks, is significantly positively in all specifications, except government banks, which is significantly negative. This result is consistent with the results of De Haas and Lelyveld (2006) and Pontines and Siregar (2014) who clearly show that the relationship between liquidity and loan is positively significant. Meanwhile, government-owned banks are not in line with expectations indicating that stateowned banks support MSMEs in meeting their credit needs even though state-owned banks lack liquidity. Furthermore, this research is in line with De Haas and Lelyveld (2014), Allen et al. (2013), De Haas and Lelyveld (2010), and Ferri et al. (2014), which suggest liquidity to show a negative and significant sign. 
Table 3: Determinants of Micro, Small and Medium Enterprises Loan

\begin{tabular}{|c|c|c|c|}
\hline \multirow{2}{*}{ Explanator Variables } & FE & RE & GMM \\
\hline & (1) & (2) & (3) \\
\hline $\operatorname{LOAN}_{\mathrm{t}-1}$ & & & $\begin{array}{c}0.1485^{\star * \star} \\
\quad(6.92)\end{array}$ \\
\hline SIZE & $\begin{array}{c}0.9164^{* * *} \\
(6.52)\end{array}$ & $\begin{array}{c}0.9113^{* * *} \\
(15.71)\end{array}$ & $\begin{array}{c}0.3106^{* * *} \\
(3.66)\end{array}$ \\
\hline PROF & $\begin{array}{c}0.0027 \\
(0.49)\end{array}$ & $\begin{array}{c}0.0052 \\
(1.04)\end{array}$ & $\begin{array}{c}0.0163^{* * *} \\
(6.15)\end{array}$ \\
\hline LIQ & $\begin{array}{c}0.9410^{* * *} \\
(2.66)\end{array}$ & $\begin{array}{c}0.5049 \\
(1.47)\end{array}$ & $\begin{array}{c}0.9183^{* * *} \\
(4.48)\end{array}$ \\
\hline SOL & $\begin{array}{c}0.09772 \\
(0.25)\end{array}$ & $\begin{array}{c}0.2837 \\
(0.78)\end{array}$ & $\begin{array}{c}0.4788^{* *} \\
(2.18)\end{array}$ \\
\hline RISK & $\begin{array}{c}-0.1853 \\
(-0.08)\end{array}$ & $\begin{array}{c}-0.9793 \\
(-0.41)\end{array}$ & $\begin{array}{c}3.9876^{\star \star *} \\
(2.61)\end{array}$ \\
\hline GDP & $\begin{array}{c}1.3150^{* \star *} \\
(6.71)\end{array}$ & $\begin{array}{c}1.2488^{\star * *} \\
(9.61)\end{array}$ & $\begin{array}{c}1.5818^{\star * *} \\
(13.55)\end{array}$ \\
\hline INF & $\begin{array}{c}-0.0454^{* * *} \\
(-3.25)\end{array}$ & $\begin{array}{c}-0.0486^{* * *} \\
(-3.45)\end{array}$ & $\begin{array}{c}-0.4245^{* * *} \\
(-11.12)\end{array}$ \\
\hline Constant & $\begin{array}{c}-12.7424^{* * *} \\
(-9.81)\end{array}$ & $\begin{array}{c}-11.9687^{* * *} \\
(-11.27)\end{array}$ & $\begin{array}{c}-7.9991^{\star * *} \\
(-8.56)\end{array}$ \\
\hline $\mathrm{R}^{2}$ within & 0.5298 & 0.5287 & \\
\hline $\mathrm{R}^{2}$ between & 0.7220 & 0.7320 & \\
\hline $\mathrm{R}^{2}$ overall & 0.6588 & 0.6651 & \\
\hline Prob $>$ F & 0.0000 & 0.0000 & \\
\hline Hausman & 0.0007 & & \\
\hline Wald chi2 & & & 1359.02 \\
\hline Sargan Test ${ }^{1}$ & & & 66.6868 \\
\hline \multirow[t]{2}{*}{$\operatorname{AR}(1)^{2}$} & & & -3.0214 \\
\hline & & & 0.0025 \\
\hline \multirow[t]{2}{*}{$\operatorname{AR}(2)^{3}$} & & & 0.50123 \\
\hline & & & 0.6162 \\
\hline Obs. & 790 & 790 & 790 \\
\hline
\end{tabular}

Note: ${ }^{* * *}$, and ${ }^{* * *}$ denote significance at $10 \%, 5 \%$ and $1 \%$ levels, respectively. ${ }^{1}$ The test for over-identifying restrictions in GMM dynamic model estimation. ${ }^{2}$ Arellano-Bond test that average autocovariance in residuals of order 1 is 0 (H0: no autocorrelation). ${ }^{3} \mathrm{Arellano}-\mathrm{Bond}$ test that average autocovariance in residuals of order 2 is 0 ( $\mathrm{HO}$ : no autocorrelation).

All estimated equations show that the effect of the capital variable on lending banks to MSMEs is not important in government banks and non-government banks. The result is inconsistent with our expectation that the higher the value of capital-to-total assets, then the possibility of credit offer that can be done by banks is also getting bigger. An explanation for this may be that the existence of bank capital regulation in Indonesia forces the bank to continue to increase its capital requirement by reducing the activity of bank loan. 
Table 4: Determinants of Micro, Small and Medium Enterprises Loan (State-owned banks)

\begin{tabular}{|c|c|c|c|}
\hline \multirow{2}{*}{ Explanator Variables } & $\mathrm{FE}$ & RE & GMM \\
\hline & (1) & (2) & (3) \\
\hline $\operatorname{LOAN}_{t-1}$ & & & $\begin{array}{c}0.2380^{* * *} \\
(9.74)\end{array}$ \\
\hline SIZE & $\begin{array}{c}0.9322^{\star * *} \\
(3.13)\end{array}$ & $\begin{array}{c}1.0717^{\star * *} \\
(10.38)\end{array}$ & $\begin{array}{l}0.2557 \\
(1.27)\end{array}$ \\
\hline PROF & $\begin{array}{c}0.0019 \\
(0.27)\end{array}$ & $\begin{array}{l}0.0029 \\
(0.43)\end{array}$ & $\begin{array}{c}0.0088^{* *} \\
(2.33)\end{array}$ \\
\hline LIQ & $\begin{array}{c}-1.1455^{\star * *} \\
(-2.28)\end{array}$ & $\begin{array}{c}-1.384^{* * *} \\
(-2.90)\end{array}$ & $\begin{array}{r}-1.0031^{* * *} \\
(-3.88)\end{array}$ \\
\hline SOL & $\begin{array}{l}-0.8241 \\
(-0.36) \\
\end{array}$ & $\begin{array}{c}-0.7896 \\
(-0.38) \\
\end{array}$ & $\begin{array}{l}-0.6097 \\
(-0.64)\end{array}$ \\
\hline RISK & $\begin{array}{c}2.1857 \\
(0.65)\end{array}$ & $\begin{array}{l}2.223 \\
(0.71)\end{array}$ & $\begin{array}{l}-2.0346 \\
(-0.90)\end{array}$ \\
\hline GDP & $\begin{array}{c}0.2932 \\
(0.80)\end{array}$ & $\begin{array}{c}0.1007 \\
(0.51)\end{array}$ & $\begin{array}{c}0.5683^{* * *} \\
(3.21)\end{array}$ \\
\hline INF & $\begin{array}{c}-0.0213 \\
(-1.24) \\
\end{array}$ & $\begin{array}{l}-0.0222 \\
(-1.30) \\
\end{array}$ & $\begin{array}{c}-0.0166^{\star \star \star} \\
(-6.69)\end{array}$ \\
\hline Constant & $\begin{array}{c}-3.2606 \\
(-1.27)\end{array}$ & $\begin{array}{c}-3.7670^{* * *} \\
(-2.24)\end{array}$ & $\begin{array}{c}1.8755^{\star * *} \\
(1.05)\end{array}$ \\
\hline $\mathrm{R}^{2}$ within & 0.4366 & 0.4358 & \\
\hline $\mathrm{R}^{2}$ between & 0.7995 & 0.8005 & \\
\hline $\mathrm{R}^{2}$ overall & 0.7264 & 0.7292 & \\
\hline Prob > F & 0.0000 & 0.0000 & \\
\hline Hausman & 0.7257 & & \\
\hline Wald chi2 & & & 1443.73 \\
\hline Sargan Test ${ }^{1}$ & & & 18.91957 \\
\hline \multirow[t]{2}{*}{$\operatorname{AR}(1)^{2}$} & & & -2.5881 \\
\hline & & & 0.0097 \\
\hline \multirow[t]{2}{*}{$\operatorname{AR}(2)^{3}$} & & & 0.02347 \\
\hline & & & 0.9813 \\
\hline Obs. & 310 & 310 & 310 \\
\hline
\end{tabular}

Note: ${ }^{*}{ }^{* *}$, and ${ }^{* * *}$ denote significance at $10 \%, 5 \%$ and $1 \%$ levels, respectively. ${ }^{1}$ The test for over-identifying restrictions in GMM dynamic model estimation. ${ }^{2}$ Arellano-Bond test that average autocovariance in residuals of order 1 is 0 ( $\mathrm{HO}$ : no autocorrelation). ${ }^{3}$ Arellano-Bond test that average autocovariance in residuals of order 2 is 0 (H0: no autocorrelation).

The loan loss provisions relative to total loans is a measure of bank risk. As I can see from my estimation results, this variable has a statistically significant negative and rather strong effect on non-governance bank lending in Indonesia. This result is in line with expectations that the relationship between risk and credit growth is negative. This means that the rising risk of banks will further decrease the bank loan. This result is consistent with the results by Cucinelli (2015), Pontines and Siregar (2014), and Guo and Stepanyan (2011), which clearly show a negative relationship between risk and credit growth of banks.

Considering the external factors related to the macroeconomic environment of the countries in which the banks are operating, I find that the coefficient of the GDP growth positively and significantly increases bank lending, particularly government banks and non-government banks. This result is in line with previous study by Dinc (2005), Chen and Wu (2014), Guo and Stepanyan (2011), Joen et al. 
Table 5: Determinants of Micro, Small and Medium Enterprises Loan (Non- state-owned banks)

\begin{tabular}{|c|c|c|c|}
\hline \multirow{2}{*}{ Explanator Variables } & FE & RE & GMM \\
\hline & (1) & (2) & (3) \\
\hline LOAN $_{\mathrm{t}-1}$ & & & $\begin{array}{c}0.04336^{* * *} \\
(3.84)\end{array}$ \\
\hline SIZE & $\begin{array}{c}0.8177^{* * *} \\
(4.90)\end{array}$ & $\begin{array}{c}0.7802^{* * *} \\
(11.35)\end{array}$ & $\begin{array}{c}0.2892^{\star * *} \\
(4.02)\end{array}$ \\
\hline PROF & $\begin{array}{l}0.0089 \\
(1.15)\end{array}$ & $\begin{array}{l}0.0132 \\
(1.79)\end{array}$ & $\begin{array}{c}0.0180^{* * *} \\
(11.55)\end{array}$ \\
\hline LIQ & $\begin{array}{c}1.1005^{\star *} \\
(2.12)\end{array}$ & $\begin{array}{c}0.4022^{* * *} \\
(0.80)\end{array}$ & $\begin{array}{c}2.0364^{* * *} \\
(15.00)\end{array}$ \\
\hline SOL & $\begin{array}{c}0.0496 \\
(0.11)\end{array}$ & $\begin{array}{l}0.3053 \\
(0.70)\end{array}$ & $\begin{array}{l}0.0747 \\
(-0.48)\end{array}$ \\
\hline RISK & $\begin{array}{c}-2.3922 \\
(-0.73)\end{array}$ & $\begin{array}{l}-3.8902 \\
(-1.19)\end{array}$ & $\begin{array}{c}2.8061^{* \star *} \\
(2.57)\end{array}$ \\
\hline GDP & $\begin{array}{c}1.8015^{\star \star *} \\
(7.36)\end{array}$ & $\begin{array}{c}1.7663^{* * *} \\
(10.57)\end{array}$ & $\begin{array}{c}2.5312^{* \star *} \\
(26.13)\end{array}$ \\
\hline INF & $\begin{array}{c}0.06507^{* * *} \\
(-3.33)\end{array}$ & $\begin{array}{c}-0.0716^{* * *} \\
(-3.6)\end{array}$ & $\begin{array}{c}-0.0550^{* * *} \\
(-17.54)\end{array}$ \\
\hline Constant & $\begin{array}{c}-15.5187^{* * *} \\
(-10.08)\end{array}$ & $\begin{array}{c}-14.4403^{* * *} \\
(-10.72)\end{array}$ & $\begin{array}{c}-15.0168^{* * *} \\
(-33.54)\end{array}$ \\
\hline $\mathrm{R}^{2}$ within & 0.5961 & 0.5940 & \\
\hline $\mathrm{R}^{2}$ between & 0.6871 & 0.7086 & \\
\hline $\mathrm{R}^{2}$ overall & 0.6476 & 0.6592 & \\
\hline Prob > F & 0.0000 & 0.0000 & \\
\hline Hausman & 0.0000 & & \\
\hline Wald chi2 & & & 11602.98 \\
\hline Sargan Test ${ }^{1}$ & & & 46.10632 \\
\hline \multirow[t]{2}{*}{$\operatorname{AR}(1)^{2}$} & & & -2.6961 \\
\hline & & & 0.0070 \\
\hline \multirow[t]{2}{*}{$\operatorname{AR}(2)^{3}$} & & & -0.02486 \\
\hline & & & 0.9802 \\
\hline Obs. & 480 & 480 & 480 \\
\hline
\end{tabular}

Note: ${ }^{* * *}$, and ${ }^{* * *}$ denote significance at $10 \%, 5 \%$ and $1 \%$ levels, respectively. ${ }^{1}$ The test for over-identifying restrictions in GMM dynamic model estimation. ${ }^{2}$ Arellano-Bond test that average autocovariance in residuals of order 1 is 0 (H0: no autocorrelation). ${ }^{3} \mathrm{Arellano}-\mathrm{Bond}$ test that average autocovariance in residuals of order 2 is 0 ( $\mathrm{H} 0$ : no autocorrelation).

(2006), and Allen et al. (2013), which showed GDP showed positive results and significant.

Finally, expected inflation, as proxied by the previous period's actual inflation, positively and significantly affects banks in lending to MSMEs. A relation with the behavior of credit inflation is negative, which means the increase in inflation will reduce bank lending. This result is consistent with Allen et al. (2013). This result indicates that banks are likely to support the government approach in curbing the inflation by limiting their lending activities in high inflationary environment. 


\section{Conclusion}

This study shows the relationship between bank-specific and macroeconomic determinants on bank lending behavior in Indonesia. The group of the bank-specific determinants of lending involves liquidity, profitability, financial risk and size of the bank. The second group of determinants relates bank lending to macroeconomics within which the banking system operates. It noted that the growth of bank credit to MSMEs decreased from $15.08 \%$ in 2013 decreased to $8.39 \%$ in 2016.

I found that bank size will increase lending behavior especially in non-government banks. Additionally, profitability affects bank lending to MSMEs positively and significant, while the coefficients of liquidity are significantly positive in all specifications, except government banks, which is significantly negative. The estimated effect of the capital variable on lending banks to MSMEs is not important in government banks and non-government banks. This result is in line with expectations that the relationship between risk and credit growth is negative for non-government banks.

Finally, macroeconomic variables, such as GDP and inflation, clearly affect bank lending to MSMEs in Indonesia. The coefficient of the GDP growth positively and significantly increases bank lending particularly government banks and non-government banks. This study then explores the relationship between inflation and bank lending and finds a negative and significant coefficient for all estimations.

The findings have several policy implications for the Indonesian government, regulatory authority and bank managers in order to improve bank profitability through bank lending: first, banks need to increase the capital injection to increase lending; bank management should enlarge retained earnings for capital to be stronger. Second, for the whole Indonesia banking industry, relevant monetary and fiscal policies should be used to control inflation to a certain extent. Finally, further studies should consider the impacts of these important factors on foreign and domestic bank lending because different bank types applying different lending technologies and organizational structures can play an important role in financing MSMEs.

\section{References}

Abe, M., Troilo, M., \& Batsaikhan, O. (2015). Financing small and medium enterprises in Asia and the Pacific. Journal of Entrepreneurship and Public Policy, 4(1), 2-32. https://doi. org/10.1108/JEPP-07-2012-0036

Allen, F.., Jackowicz, K., \& Kowalewski, O. (2013). The Effects of Foreign and Government Ownership On Bank Lending Behavior During A Crisis in Central and Eastern Europe. Wharton Financial Institutions Center Working Paper No. 13-25. Wharton Financial Institutions Center, University of
Pennsylvania, Philadelphia, PA, United States. https://mpra. ub.uni-muenchen.de/48059/

Arellano, M., \& Bond, S. R. (1991). Some tests of specification for panel data: Monte Carlo evidence and an application to employment equations. Review of Economic Studies, 58(2), 277-297. https://doi.org/10.2307/2297968.

Azis, A., \& Rusland, A. H. (2009). Bank Indonesia's Role in Supporting the Development of Micro, Small and Medium Enterprises. Bank Indonesia. Jakarta. Retrieved June 10, 2020 from: https://www.bi.go.id/id/publikasi/seri-kebanksentralan/ Documents $/ 21 . \% 20$ Peranan\%20BI\%20dalam\%20mendukung \%20pengembangan\%20usaha $\% 20$ mikro\%20kecil\%20dan\%20 menengah.pdf

Baltagi, B. (2001). Econometrics analysis of panel data. West Sussex, UK: Wiley and Sons Ltd.

Beck, T., Demirguc-Kunt, A., \& Levine, R. (2005). SMEs, growth, and poverty: Cross-country evidence. Journal of Economic Growth, 10(3), 199-229. https://doi.org/10.1007/s10887-0053533-5

Beck, T., Demirgüç-Kunt, A., \& Maksimovic, V. (2008). Financing patterns around the world: Are small firms different? Journal of Financial Economics, 89(3), 467-487. https://doi.org/10.1016/j. jfineco.2007.10.005

Behr, P., Foos, D., \& Norden, L. (2017). Cyclicality of SME lending and government involvement in banks. Journal of Banking and Finance, 77, 64-77. https://doi.org/10.1016/j. jbankfin.2017.01.010

Behr, P., Norden, L., \& Noth, F. (2013). Financial constraints of private firms and bank lending behavior. Journal of Banking and Finance, 37(9), 3472-3485. https://doi.org/10.1016/j. jbankfin.2013.05.018

Berger, A. N., Miller, N. H., Petersen, M. A., Rajan, R. G., \& Stein, J. C. (2005). Does function follow organizational form ? Evidence from the lending practices of large and small banks. Journal of Financial Economics, 76, 237-269. https://doi. org/10.1016/j.jfineco.2004.06.003

Berger, A. N., Schaeck, K., \& Berger, A. N. (2017). Capital Relationship Strength and the Use of Venture, Journal of Money, Credit and Banking, 43(2), 461-490. https://doi. org $/ 10.2307 / 20870058$

Berger., A. N., Rosen, R. J., \& Udell, G. F. (2001).The Effect of Market Size Structure on Competition: The Case of Small Business Lending. Federal Reserve Bank of Chicago Working Paper WP 2001-10. Federal Reserve Bank of Chicago, Chicago, Illinois. Retrieved June 10, 2020 from: http://www.chicagofed. org/digital_assets/publications/working_papers/2001/wp200110.pdf

Bouvatier, V., \& Lepetit, L. (2012). Effects of loan loss provisions on growth in bank lending: Some international comparisons. International Economics, 132, 91-116. https://doi.org/10.1016/ $\mathrm{S} 2110-7017(13) 60059-1$

Boyd, J. H., \& Champ, B. (2006). Inflation, Banking and Economic Growth. Cleveland, OH: Federal Reserve Bank of Cleveland. 
Chen, G., \& Wu, Y. (2014). Bank Ownership And Credit Growth In Emerging Markets During And After The 2008-09 Financial Crisis A Cross Regional Comparison. IMF Working Paper No14/171. Washington, DC: International Monetary Fund. Available at: https://www.imf.org/external/pubs/ft/wp/2014/ wp14171.pdf

Chmielewski, T. (2005). Bank Risks, Risk Preferences and Lending. MPRA Paper 5131. University Library of Munich, Germany. Available at: https://mpra.ub.uni-muenchen.de/5131/

Choi, M. J., Gutierrez, E., \& Peria, M. S. M. (2013). Dissecting Foreign Bank Lending Behavior During the 2008-2009 Crisis. Working Paper No. 6674. The World Bank \& Latin America and the Caribbean Region Finance and Private Sector Development Unit Policy Research. Available at: http:// documents1.worldbank.org/curated/en/858901468326421222/ pdf/WPS6674.pdf

Chu, L., Mathieu, R., Robb, S., \& Zhang, P. (2007). Bank capitalization and lending behavior after the introduction of the Basle Accord. Review of Quantitative Finance and Accounting, 28(2), 147-162. https://doi.org/10.1007/s11156-006-0009-4

Cucinelli, D. (2015). The Impact of Non-performing Loans on Bank Lending Behavior: Evidence from the Italian Banking Sector. Eurasian Journal of Business and Economics, 8(16), 59-71. https://doi.org/10.17015/ejbe.2015.016.04

De Haas, R., \& van Lelyveld, I. (2010). Internal capital markets and lending by multinational bank subsidiaries. Journal of Financial Intermediation, 19(1), 1-25. https://doi.org/10.1016/j. jfi.2009.02.001

De Haas, R., \& van Lelyveld, I. (2014). Multinational banks and the global financial crisis: Weathering the perfect storm? Journal of Money, Credit and Banking, 46(1), 333-364. https://doi. org/10.1111/jmcb.12094

Díaz-Chao, Á., Ficapal-Cusí, P., \& Torrent-Sellens, J. (2017). Did small and medium enterprises maintain better jobs during the early years of the recession? Job quality multidimensional evidence from Spain. European Management Journal, 35(3), 396v413. https://doi.org/10.1016/j.emj.2016.06.006

Dinç, I. S. (2005). Politicians and banks: Political influences on government-owned banks in emerging markets. Journal of Financial Economics, 77(2), 453-479. https://doi.org/10.1016/j. jfineco.2004.06.011

Ferri, G., Kalmi, P., \& Kerola, E. (2014). Does bank ownership affect lending behavior? Evidence from the Euro area. Journal of Banking and Finance, 48, 194-209. https://doi.org/10.1016/j. jbankfin.2014.05.007

Fungáčováa, Z., Herralaa, R., \& Weillc, L. (2013). The Influence Of Bank Ownership On Credit Supply: Evidence From The Recent Financial Crisis. Emerging Markets Review, 15, 136147. https://doi.org/10.1016/j.ememar.2013.02.002

Gambacorta, L., \& Marques-Ibanez, D. (2011). The Bank Lending Channel: Lessons From The Crisis. BIS Working Papers No. 345. Monetary and Economic Department. Bank for International Settlements. Basel, Switzerland.
Goldberg, L. G., Cole, R. A., \& White, L. J. (2002). Cookie-Cutter Versus Character: The Micro Structure of Small Business Lending by Large and Small Banks. Journal of Financial and Quantitative Analysis, 39(2), 227-251. https://doi.org/10.1017/ S0022109000003057

Guo, K., \& Stepanyan, V. (2011). Determinants of Bank Credit in EMEs. IMF Working Paper No. 11/51. Washington, DC: International Monetary Fund. Available at: https:/www.imf. org/external/pubs/ft/wp/2011/wp1151.pdf

Haltiwanger, J., Jarmin, R. S., \& Miranda, J. (2013). Who creates jobs? Small versus large versus young. Review of Economics and Statistics, 95(2), 347-361. https://doi.org/10.1162/ REST_a_00288

International Financial Corporation. (2016). Women-owned SMEs in Indonesia: A Golden Opportunity for Local Financial Institutions. IFC and USAID. Retrieved June 20, 2020 from: https://documents.worldbank.org/curated/ en/737221477568795492/UKM-yang-dimiliki-wanita-diIndonesia-kesempatan-emas-untuk-institusi-keuangan-lokal

Jeon, Y., Miller, S. M., \& Natke, P. A. (2006). Do Foreign Bank Operations Provide A Stabilizing Influence In Korea? The Quarterly Review of Economics and Finance. 46(1), 82-109. https://doi.org/10.1016/j.qref.2004.06.006

Jiménez, G., \& Saurina, J. (2006). Credit Cycles, Credit Risk, and Prudential Regulation. International Journal of Central Banking, 2, 65-98.

Kishan, R. P., \& Opiela, T. P. (2000). Bank Size, Bank Capital, and the Bank Lending Channel. Journal of Money, Credit and Banking, 32(1), 121. https://doi.org/10.2307/2601095

La Porta, R., Lopez-de-Silanes, F., Shleifer, A., \& Vishny, R. W. (2002) Investor Protection and Corporate Valuation. Journal of Finance, 57(3), 1147-1170. https://doi.org/10.1111/15406261.00457

Micco, A., \& Panizza, U. (2006). Bank ownership and lending behavior. Economics Letters, 93(2), 248-254. https://doi. org/10.1016/j.econlet.2006.05.009

Modigliani, F., \& Miller, M. H. (1958). The Cost of Capital, Corporation Finance and the Theory of Investment. American Economic Review, 48(3), 261-97.

Molyneux, P., Remolona, E., \& Seth, R., (1998). Modeling Foreign Bank Performance and Lending Behavior. Financial Markets, Institutions and Instruments, 7, 26-41. https://doi. org/10.1111/1468-0416.00022

Nguyen, D. D., \& Nguyen, A. H. (2020). The Impact of Cash Flow Statement on Lending Decision of Commercial Banks: Evidence from Vietnam. Journal of Asian Finance, Economics and Business, 7(6), 85-93. https://doi.org/10.13106/jafeb.2020. vol7.no6.085

Panagopoulos, Y., \& Spiliotis, A. (1998). The determinants of commercial banks' lending behavior: Some evidence for Greece. Journal of Post Keynesian Economics, 20(4), 649-672. https://doi.org/10.1080/01603477.1998.11490172 
Pham, D. S. D. (2013). The determinants of Vietnamese banks' lending behavior: A theoretical model and empirical evidence. Journal of Economic Studies, 42(5), 861-877. https://doi. org/10.1108/JES-08-2014-0140

Pontines, V., \& Siregar, R. Y. (2014). How Should We Bank With Foreigners? An Empirical Assessment of Lending Behaviour of International Banks to Six East Asian Countries. International Review of Economics \& Finance, 29, 552-568. https://doi. org/10.1016/j.iref.2013.08.006

Ramcharran, H. (2017). Bank lending to small business in India: Analyzing productivity and efficiency. Quarterly Review of Economics and Finance, 65, 16-24. https://doi.org/10.1016/j. qref.2016.06.003

Saurina, J. (2009). Loan Loss Provisions in Spain. A Working Macroprudential Tool. Revista de Estabilidad Financiera of the Banco de España, 17, 11-26. Available at: https://www.bde.es/f/ webbde/Secciones/Publicaciones/InformesBoletinesRevistas/ RevistaEstabilidadFinanciera/09/Noviembre/ief0117.pdf

Shen, Y., Shen, M., Xu, Z., \& Bai, Y. (2009). Bank Size and Smalland Medium-sized Enterprise (SME) Lending: Evidence from China. World Development, 37(4), 800-811. https://doi. org/10.1016/j.worlddev.2008.07.014

Susilo, Y. S. (2010). The Role of Banking in MSME Financing in DIY Province. Journal of Finance and Banking, 14(3), 467478. http://jurnal.unmer.ac.id/index.php/jkdp/article/view/988

Takasu, Y., \& Nakano, M. (2019). Conservative Loan Loss Allowance and Bank Lending. Journal of Asian Finance, Economics and Business, 6(3), 9-18. https://doi.org/10.13106/ jafeb.2019.vol6.no3.9

Vo, X. V. (2018). Bank lending behavior in emerging markets. Finance Research Letters, 27, 129-134. https://doi. org/10.1016/j.frl.2018.02.011

Xuan, V. N. (2020). Determinants of Investment Capital Size: A Case of Small and Medium-Sized Enterprises in Vietnam. Journal of Asian Finance, Economics and Business, 7(6), 1927. https://doi.org/10.13106/jafeb.2020.vol7.no6.019

Yudaruddin, R. (2017). Economic Conditions and Lending Behavior: Evidence from the Regional Development Banks in Indonesia. International Journal of Economic Research, 14(13), 105-114. 